Portland State University

PDXScholar

TREC Final Reports

Transportation Research and Education Center

(TREC)

$11-2011$

\title{
A Capping Case Study: Integrating Freight Rail into a Community Setting
}

Jeff Schnabel

Portland State University, jjsch@pdx.edu

Tristan Brasseur

Portland State University

Follow this and additional works at: https://pdxscholar.library.pdx.edu/trec_reports

Part of the Infrastructure Commons, Transportation Commons, and the Urban Studies and Planning Commons

Let us know how access to this document benefits you.

\section{Recommended Citation}

Schnabel, Jeff and Tristan Brasseur. A Capping Case Study: Integrating Freight Rail into a Community Setting. OTREC-RR-11-26. Portland, OR: Transportation Research and Education Center (TREC), 2011. https://doi.org/10.15760/trec.10

This Report is brought to you for free and open access. It has been accepted for inclusion in TREC Final Reports by an authorized administrator of PDXScholar. Please contact us if we can make this document more accessible: pdxscholar@pdx.edu. 


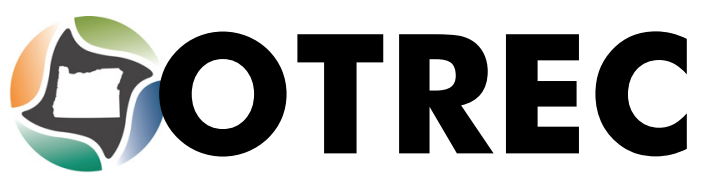

FINAL REPORT

OTREC-RR-11-26 November 2011 



\title{
A Capping Case Study: Integrating Freight Rail into a Community Setting
}

\author{
Final Report \\ OTREC-RR-11-26 \\ by \\ Jeff Schnabel \\ Portland State University \\ Tristan Brasseur \\ Portland State University
}

for

Oregon Transportation Research and Education Consortium (OTREC)

P.O. Box 751

Portland, OR 97207

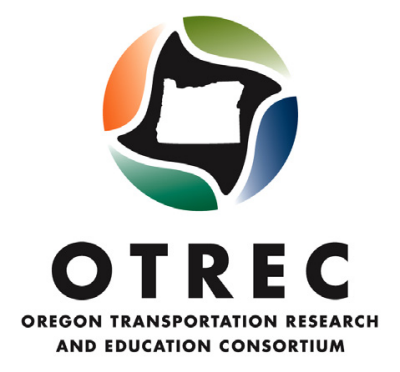

November 2011 



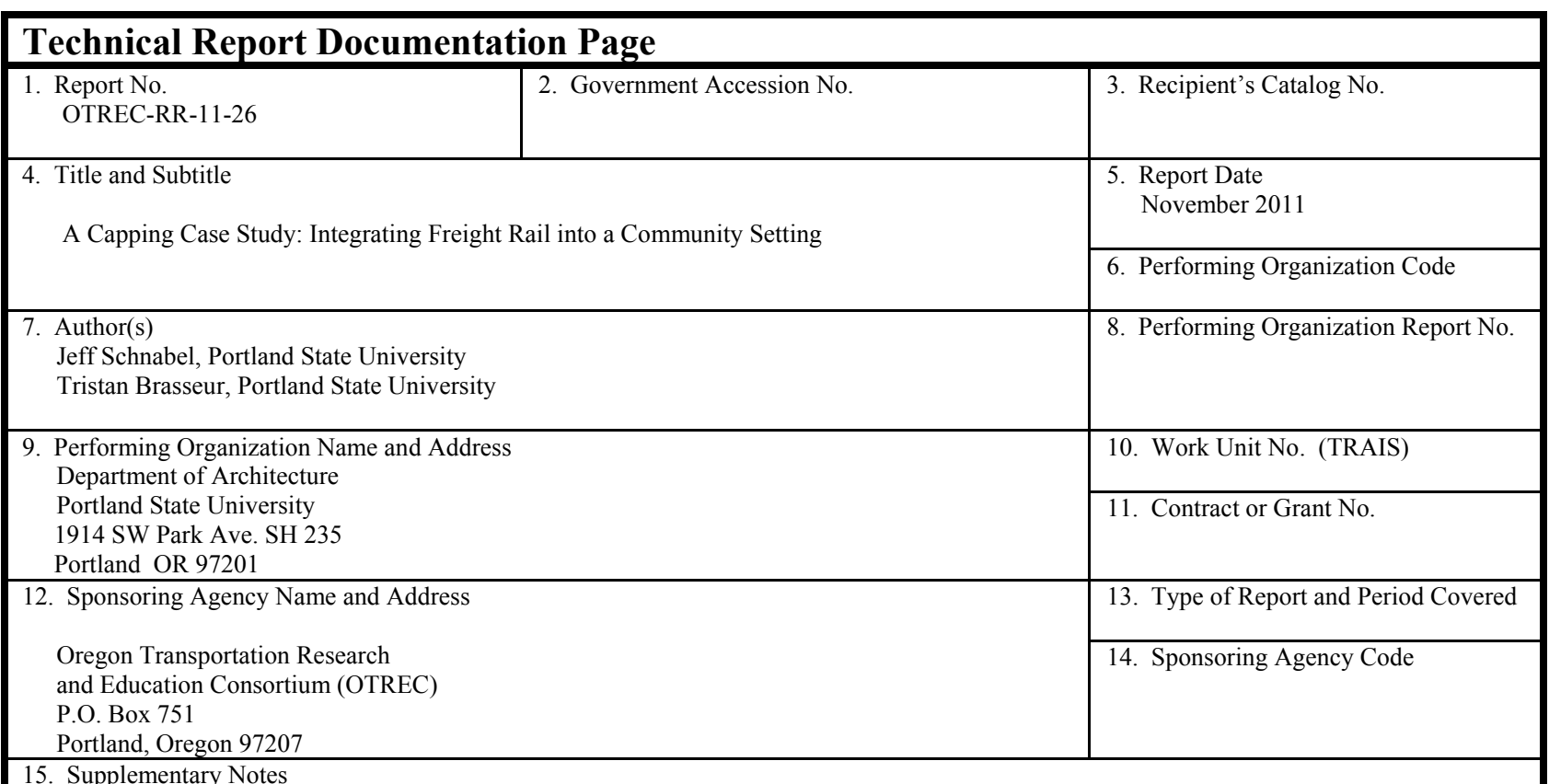

15. Supplementary Notes

\section{Abstract}

This investigation seeks to explore specific design solutions that could potentially enhance the capabilities of heavy rail facilities while increasing their safety and reducing their environmental and community impacts.

Using Portland's Brooklyn Rail Yard as the study site, this case study explored the potential of structural platforms (caps) built above the existing rail yards to provide development space for expanding rail capacity and rail related activities. The potential for capping to reduce /eliminate conflicts between rail and non-rail uses will also be investigated. Finally, the various designs were presented for caps at the rail yard.

Capping projects (the development of air rights above an existing use) have been successfully employed over other forms of transportation. Duluth Minnesota, Barcelona Spain, and Seattle Washington have each employed capping strategies to mitigate the impact of freeways on the urban fabric. This study will explore the potential of caps to address the specific conditions of a privately held freight rail facility.

Key stakeholders will be identified including Union Pacific Railroad, TriMet, Portland Development Commission, Brooklyn Neighborhood Association, Creston-Kenilworth Neighborhood Association and Reed Neighborhood Association. The stakeholders will be interviewed to identify the needs and impacts of freight rail on this particular site. Consultants with expertise on the mitigation of the identified impacts will be interviewed and their input documented. Precedents for potential solutions will be identified and documented.

Sites in the Brooklyn Rail Yard will be selected as areas for additional study based upon their potential to illustrate the impact of the proposed solutions. Once the sites are selected a master plan will be generated that reflects input from the stakeholders, consultants, and precedent investigations. The master plan will be presented to stakeholders and consultants for their response to the proposed solutions.

17. Key Words

freight rail

Brooklyn Rail Yard

sound mitigation

Union Pacific Railroad

air rights development

capping

19. Security Classification (of this report)

Unclassified
18. Distribution Statement

No restrictions. Copies available from OTREC: www.otrec.us 


\section{ACKNOWLEDGEMENTS}

This project was funded by the Oregon Transportation Research and Education Consortium (OTREC). Support was provided by Portland State University's Department of Architecture.

\section{DISCLAIMER}

The contents of this report reflect the views of the authors, who are solely responsible for the facts and the accuracy of the material and information presented herein. This document is disseminated under the sponsorship of the U.S. Department of Transportation University Transportation Centers Program in the interest of information exchange. The U.S. Government assumes no liability for the contents or use thereof. The contents do not necessarily reflect the official views of the U.S. Government. This report does not constitute a standard, specification, or regulation. 


\section{TABLE OF CONTENTS}

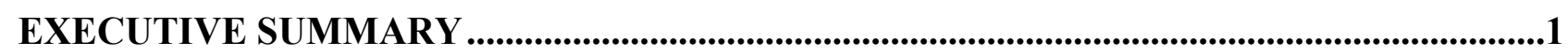

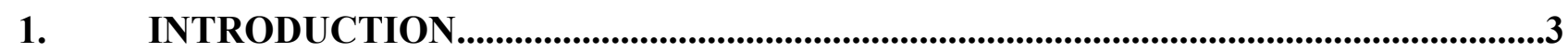

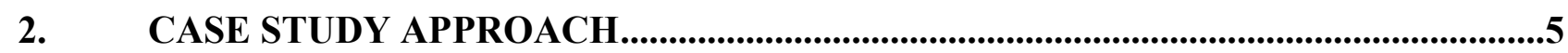

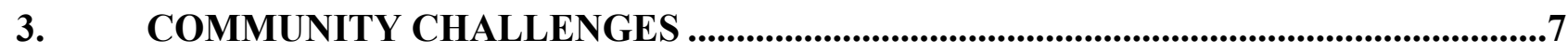

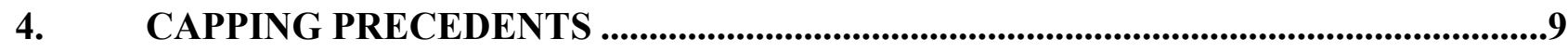

5. FREIGHT RAIL IMPACT MITIGATION PRECEDENTS .......................................11

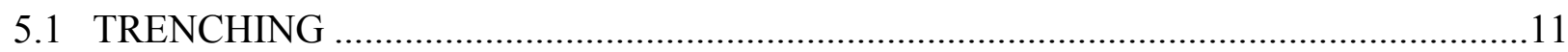

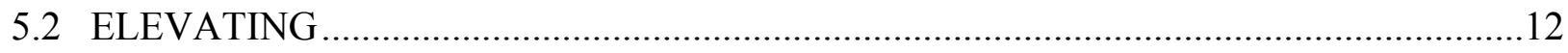

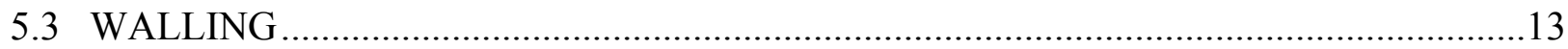

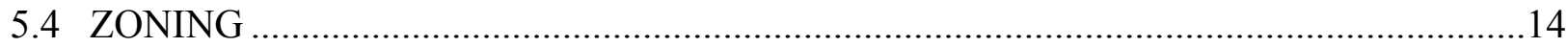

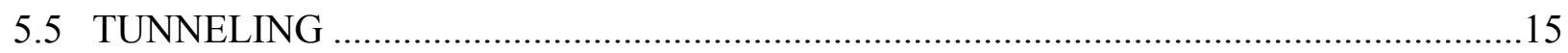

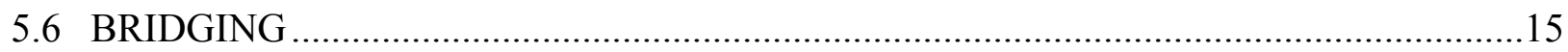

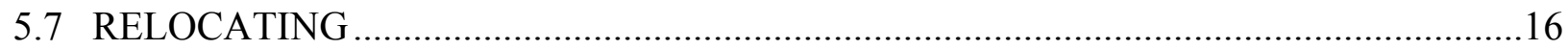

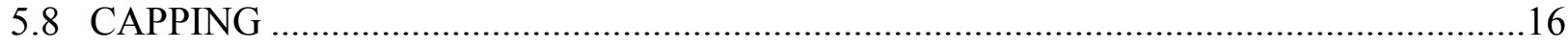

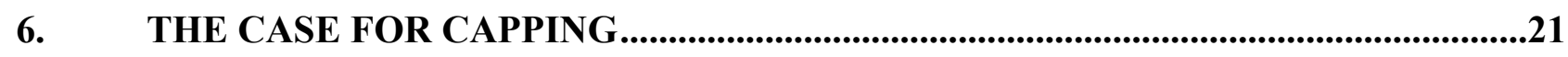

7. A CAPPING STRATEGY FOR THE BROOKLYN RAIL YARD...............................23

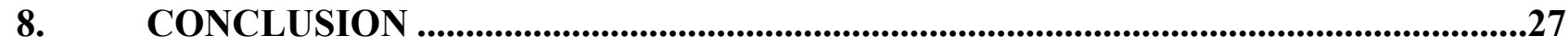

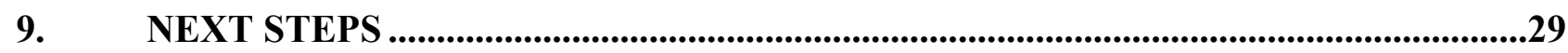

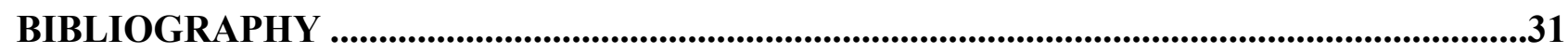

APPENDIX A. NEIGHBORHOOD SURVEY AND RESPONSES...............................................33 


\section{EXECUTIVE SUMMARY}

Because of economic, environmental and transportation benefits, freight rail figures to be an important part of local and national transportation strategies. However, the location of freight rail within urban settings impacts adjacent communities and can present challenges to rail operations. For the Brooklyn Rail Yard in Portland, OR, the noise from train signals and train operations is cited as one of the key impacts. The lack of connectivity between neighborhoods due to the size and location of the rail yard is also considered a significant impact, along with safety, pollution, trespassing and aesthetics. Both operational and physical modifications have been used to mitigate many of these impacts throughout the country. A strategy that has not been employed is that of capping. Capping is the development of the air rights above another use with a new structural platform that supports additional development. It allows the existing ground-level activities to continue while offering significant new development opportunities above. In other capping projects this development has included parks, civic buildings and commercial activities. Capping appears to have value as a mitigation strategy for the Brooklyn Rail Yard because it deals comprehensively with the impacts identified by adjacent neighborhoods, supports and potentially expands the existing rail operations, provides new amenities and revenue opportunities for the community, and addresses connectivity needs identified by various city agencies. Using this as a case study, four potential capping sites over the Brooklyn Rail Yard are identified and the possible contributions each location offers are discussed. 


\section{INTRODUCTION}

Freight rail provides more energy-efficient movement of goods and is less polluting than truck transportation, averaging three to four times more fuel efficiency. According to a 2000 study by the American Association of State Highway and Transportation Officials (AASHTO), a fuel savings of nearly 200 million gallons annually could be achieved by moving 10 percent of the freight from trucks to rail. This also translates into environmental benefits in reduced nitrogen oxides and particulate emissions. Freight rail, particularly for heavy materials or large volumes, can also be more cost-effective than truck movements (AASHTO, 2003). Lastly, moving goods by freight rail can help to ease traffic congestion. Switching to freight rail for some communities can mean slowing congestion by removing more trucks from traffic and diminishing their interaction with passenger vehicles (NCHRP, 2004).

Oregon has 2,400 miles of active track and 21 operating railroads. Two are Class I railroads, the Union Pacific and the Burlington Northern \& Santa Fe. One Union Pacific line runs from Portland east through Pendleton, La Grande, Baker City and Boise. The other Union Pacific line runs from Portland south through Eugene and across the Cascades into California.

A recent study commissioned by the Port of Portland, Freight Rail and the Oregon Economy, indicates that although the rail industry is stable, productive and competitive enough to increase business, railroads are not in the financial position to increase capacity quickly due to the capitalintensive nature of the system's ongoing needs. On average, railroads reinvest 18 percent of revenues back into improvements. With reasonable economic growth, total freight is expected to double in the next 20 years. If railroads are not able to maintain their current share of that increase, the study notes, additional tonnage will travel by truck, increasing public-sector costs for highways and private-sector costs for transportation (State of Oregon, May 2004).

Bulk goods (grains and minerals) that move through Portland constitute more than half of the region's annual export tonnage. Most of the bulk goods to be exported arrive by unit trains. However, about 40 percent of grain exports arrive in Portland by barge. The future promises even more bulk goods via both unit trains and barges, through both the Port of Portland and private facilities (Metro, 1999).

Rail freight movement in the area is not expected to grow as fast as other segments of the economy. The volume of domestic rail freight is expected to increase by less than 2 percent in the medium term and less than 1.5 percent in the long term. International rail freight is expected to grow about twice as fast as domestic: 4.4 percent in the short term and 3.9 percent in the long term (Metro, 1999).

\section{Freight Rail Impact on Urban Residential Communities}

According to the report NCHRP Synthesis 320: Integrating Freight Facilities and Operations with Community Goals, the amount of freight rail nationally is increasing due in part to strategies to reduce truck congestion. The study suggests that because of continued population growth in the 
U.S. and increases in land development the conflicts between transportation and other land uses will become more frequent. The impact of these conflicts may become more profound (NCHRP, 2003).

When freight rail activities share proximity with nonindustrial uses, there is potential for negative impacts to arise. NCHRP 320 identifies potential impacts, such as interruptions to traffic flow, which cause backups and dangerous conflicts through at-grade crossings. The movement of hazardous materials can be potentially dangerous due to possible terrorist threats, which pose further risks to adjacent communities near rail. Rail corridors can attract trespassers, which can result in theft and destruction of property in addition to injury or loss of life.

As freight-based transportation increases, communities may be less tolerant of the new activity. Freight facilities may impede other community economic development goals. The visible storage of train cars, poor maintenance of rights-of way, noise and increased truck traffic could adversely affect adjacent land values. The diesel emissions from idling trains can adversely affect local air quality. The light emitted from nighttime operations of freight facilities and vibrations from heavy trains can be a nuisance to adjacent neighborhoods. Furthermore, noise from train signals, multimodal equipment and freight operations is undesirable.

While freight rail is important to the Oregon economy and has some distinct advantages, the interactions within the urban setting and at the community level can be unwelcome. How then can urban freight rail co-exist within the urban, community-level context? This case study examines a specific urban rail yard in Portland to develop potential capping alternatives to address some of the undesirable byproducts of freight rail operations. The goal also is to improve interactions between the freight rail yard and the surrounding neighborhoods to increase community cohesion. Capping is a strategy that builds new land/space for development in the air rights over transportation systems. It has been implemented in other transportation systems to address some of the issues that arise for freight rail facilities and operations that occur adjacent to neighborhoods. 


\section{CASE STUDY APPROACH}

The site chosen for the case study is the Brooklyn Rail Yard. It is located in southeast Portland in an urban setting that is adjacent to both industrial and residential communities. It is an intermodal freight yard that primarily consists of trailers on flatcars with some containers on flatcars. The yard is owned and operated by the Union Pacific Railroad. In addition to the intermodal freight, there are carloads of liquid sugar, lumber and cement switched into trains within the yard for delivery to and from local industries. As a common carrier, Union Pacific also handles a variety of commodities that run through the yard as through-freights.

Currently, one intermodal train originates and one intermodal train terminates at the yard six days a week. Amtrak operates three passenger trains in both directions each day, all of which pass by the yard on the mainline. Approximately six freight trains operate through Brooklyn in both directions for a total of 12 per day. These trains also pass through the yard on the mainline. Occasionally, these trains will "set out" cars in the yard before continuing on to their destinations. There are two industries adjacent to the yard that deliver and pick up cars six days a week. The Portland and Western Railroad delivers and picks up cars from the yard daily, three to five times a week. There is also a daily transfer of railcars to and from the Albina Yard. At less frequent intervals, there are work trains passing through the yard with track maintenance equipment and trains that transport empty flatcars back to a location where they are needed.

Intermodal containers are loaded and unloaded from railcars using rubber-tired cranes that straddle the track. The containers are either lifted off of a truck trailer and placed on a railcar or lifted off the railcar and placed on an empty truck trailer chassis. The intermodal containers or empty chassis are spotted parallel to the tracks by either a yard hostler or commercial trucker. Longer trains are built up by coupling segments south of the yard.

Approximately 300 trucks per day come into and out of the yard to handle intermodal shipments. Union Pacific is considering consolidating its intermodal operations from the Albina Yard (located in a more industrial site) to the Brooklyn Yard, which would increase these numbers.

In Figure 1, the boundary of the Brooklyn Rail Yard is outlined in red. The black structures indicate the locations of light industrial, warehouse and commercial uses. The existing residential areas are shaded green. Public access streets are shown in gray. The rail yard is surrounded immediately by light industrial and warehousing uses. To the southeast, the industrial district provides a reasonable buffer to adjacent housing. However, residential uses have been developed within a block of the rail yard in both the Brooklyn and Sellwood/Moreland neighborhoods to the west. The close proximity of residential uses to the rail yard appears to heighten the perceived negative impacts of the rail activity, which led to its selection as the case study site. 
Figure 1. Map of surrounding land uses
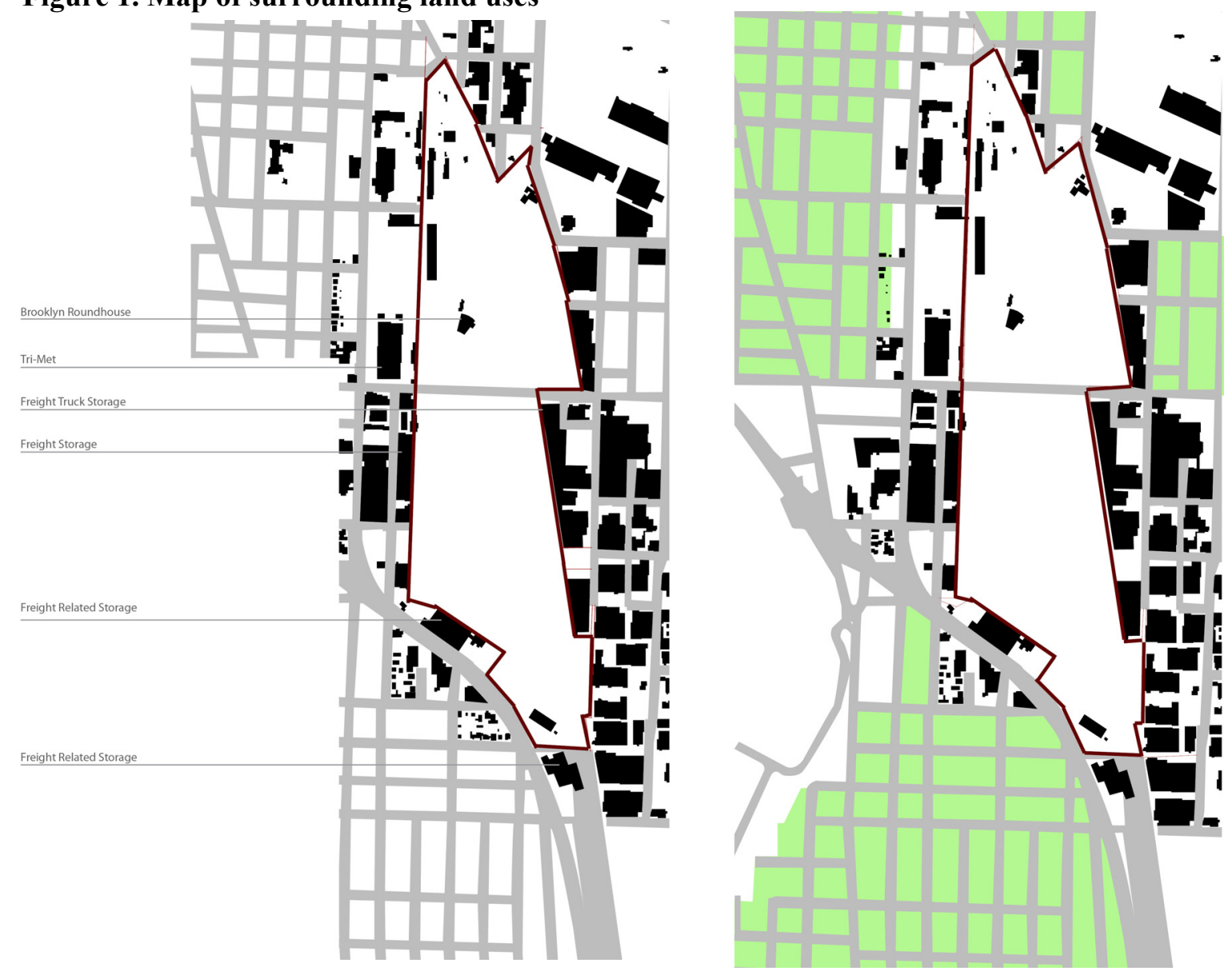

To develop and examine options for this case study, the team used the following approach:

- Identify stakeholders. The case study team identified on-site, freight-related industries, adjacent community organizations and adjacent business organizations that would provide more insight into the interactions of the freight yard on their business and/or community.

- Interview stakeholders. The stakeholders were individually interviewed to identify their perception of the possibilities and constraints of the Brooklyn Rail Yard.

- Literature review. A literature review was undertaken of existing projects that used capping strategies for the purpose of mitigation, and used these to help determine capping options.

- Document site conditions. The case study team compiled existing site and planning documentation for the Brooklyn Rail Yard study site. This information served as the base condition for the physical planning effort.

- Single-site physical planning. Using one small portion of the Brooklyn Rail Yard, ideas and intentions emerged out of the interviews to help planning/design investigations. Physical models and digital drawings were developed.

- Stakeholder review and response to physical planning. The concepts from the physical planning effort were presented to each of the stakeholders to identify the potential strengths and weaknesses of each scheme. Their evaluations were captured as part of the investigation and documentation. 


\section{COMMUNITY CHALLENGES}

Community connectivity is a significant challenge for neighborhoods surrounding the Brooklyn Rail Yard and lines. The rail lines prevent easy pedestrian and bicycle access from one neighborhood to the next as well as to the river and downtown Portland. The Brooklyn neighborhood shares the greatest stretch of boundary with the Brooklyn Rail Yard. The Reed, Creston - Kenilworth, and Sellwood-Moreland neighborhoods also share adjacencies. The Eastmoreland and Hosford-Abernathy neighborhoods are near the rail lines to the south and north, respectively.

In order to better understand potential impacts of freight rail activities on the neighborhoods, questionnaires were sent to the Land Use/Planning committees from each of the neighborhood associations (See Appendix A). The team also held a number of community meetings to gain a better understanding of the current situation and the conflicts that exist between the rail yard, city and surrounding neighborhoods. This section provides an overview of some of the challenges described in the meetings and surveys.

When the Brooklyn Rail Yard was first established, it was surrounded by a great deal more industry and a great deal less housing. Many of the current concerns are the result of zoning and development changes that have brought residential uses closer to the rail yard. This proximity of housing to the rail yard appears to contribute significantly to the perceived negative impacts.

The most frequent complaint Union Pacific receives is noise. In particular, sounding locomotive horns at crossings is a nuisance. Though a nuisance, the horn loudness and duration are required and dictated by federal law. In addition to the horn noise, the railroad has received complaints about noise created from the coupling of cars, slack action in moving trains, idling locomotives, and back-up beepers on intermodal cranes.

Union Pacific has also received complaints from the adjacent neighborhoods for parking trains along the tracks. Neighbors complain that they are unsightly. In addition, concern has been expressed about transients potentially getting off trains in the area. This is a shared concern as Union Pacific lists trespassing by freight hoppers, those illegally crossing tracks, and joggers in the right-of-way as challenges to its safety goals.

From Union Pacific's perspective, there is also conflict between trains departing the yard and commuters wanting to get to and from the east and west sides of the river. There are too few gradeseparated crossings for commuters to use to avoid being blocked by a train.

There are operational challenges to the urban setting of the Brooklyn Rail Yard. The existing Holgate Street overpass leaves only a narrow opening for tracks. Six intermodal tracks are shorter than Union Pacific would like them to be, which limits their utility. In addition, access to highways could be improved. 
Union Pacific is constrained by a 1956 injunction (modified in 2004) that dictates the manner and frequency with which it can couple (double-over) cars from multiple tracks to make up a train. These constraints affect Union Pacific's ability to efficiently handle the rail cars. While Union Pacific currently views the available right-of-way as sufficient, if more space were made available it would likely be used for additional parking for intermodal containers and yard tracks. 


\section{CAPPING PRECEDENTS}

Capping transportation systems is not a new idea and has been successfully implemented over freeways, rail lines and rivers. In a literature review conducted by the team, several projects were identified to provide further understanding of capping strategies applied internationally. These include the following:

- $\quad$ Ronda De Dalt, Barcelona Spain. The Ronda De Dalt is a freeway that circles around Barcelona for 26 miles. Built to accommodate additional traffic anticipated for the 1992 Summer Olympics, the depressed roadway had the potential to seriously interrupt the connections between neighborhoods. To mitigate these impacts, caps were added at regular intervals. The caps were topped with housing, parks, public art, parking, pedestrian walkways and vehicular connections.

- Lake Park, Duluth MN. As part of the Interstate 35 Extension Project, the Minnesota Department of Transportation added a $2 \frac{1}{2}$-acre platform above the freeway to reconnect Duluth to Lake Superior. In addition to providing pedestrian connections, the cap created parks and open space, including the Duluth Rose Garden. When constructed in 1992, the project cost $\$ 220$ million. By 1998, the project had stimulated an estimated $\$ 800$ million to $\$ 900$ million in private investment and caused adjacent land values to double.

- $\quad$ Mercer Island, WA. On Mercer Island, nearly 20 percent of Interstate 90 was covered with lids that created 28 acres of new park land. The cap features a 12-mile bike route which connects several sports fields and play meadows.

- $\quad$ Freeway Park, Seattle WA. Built in 1976, Freeway Park is a 5.2-acre cap that spans Interstate 5 and a city-owned parking lot. The ADA-compliant park makes a connection between downtown and First Hill. The abstract concrete boulders and large evergreen trees create an abstract Cascade mountain landscape. The fountains were carefully designed and located to drown out the noise from the freeway below.

- Convention Center, Seattle WA. A later addition to Freeway Park, also spanning Interstate 5, the Convention Center is a 307,000-square-foot facility that hosts exhibitions, trade shows and conferences. Much of the facility is open to the public and it features restaurants and an art gallery.

- $\quad$ Copley Place, Boston MA. Built in 1984, Copley Place is an office/retail development designed to reconnect two neighborhoods in Boston's Back Bay. A portion of the 9.5-acre project is built in the air rights above the Massachusetts Turnpike and adjacent railroad tracks.

- $\quad$ Ponte Vecchio, Florence Italy. This medieval bridge spans the Arno River, historically a major artery for transportation and commerce. Built in 1345, the shops that line the top of 
the structure housed butchers in the early days. Today the shops are largely occupied by jewelers and art dealers.

- $\quad$ Penn Station, New York City. Though technically not a cap, Penn Station is an example of significant development being created over active rail lines. Below Madison Square Garden and two office towers is a major commuter rail hub serving 600,000 passengers per day.

In 1998, the Community Assistance Team Demonstration Project led by the American Society of Landscape Architects explored the feasibility of caps over Interstate 405 in Portland. With the assistance of city agencies, the Oregon Department of Transportation and community members identified 11 potential capping locations. The programs and functions for the proposed caps included extensions of the Portland State University campus, housing, parks, civic buildings, retail shops and parking. All of the proposed caps embraced the qualities of connecting neighborhoods, providing multimodal transportation and contributing to economic development. It was estimated that the caps could provide 1,000 new housing units, 650,000 square feet of commercial space, 2,200 parking spaces, six acres of parks, two acres of indoor recreation, and 50,000 square feet of civic/exhibition space. The findings of a blue ribbon committee, formed after the initial report, indicated that the cost of a new platform built across the freeway (to accommodate four stories maximum) would be comparable to the cost of bare ground of the same acreage in the downtown district. The study was a visionary effort that was never realized (American Society of Landscape Architects, 1998). 


\section{FREIGHT RAIL IMPACT MITIGATION PRECEDENTS}

Along with capping precedents, other mitigation strategies have been used to reduce the impact of noise, environmental and traffic impacts of rail operations on neighboring communities. The team reviewed other general strategies documented in NCHRP Synthesis 320: Integrating Freight Facilities and Operations with Community Goals to determine whether these would help to achieve some of the community goals. The strategies most relevant to the case study are highlighted in Table 1.

\begin{tabular}{|c|c|}
\hline Objective & Mitigation Strategies \\
\hline \multirow{5}{*}{$\begin{array}{l}\text { Decrease Noise and } \\
\text { Vibrations }\end{array}$} & Create "no whistle" rail zones. \\
\hline & Install continuous welded rail. \\
\hline & Build sound walls or berms. \\
\hline & Limit hours of operation. \\
\hline & $\begin{array}{l}\text { Create buffer zones between industrial and residential land } \\
\text { uses. The two-block buffer zones would exclude residential } \\
\text { uses. }\end{array}$ \\
\hline \multirow{4}{*}{$\begin{array}{l}\text { Improve Traffic Flow } \\
\text { and Reduce } \\
\text { Congestion }\end{array}$} & Replace at-grade rail crossings with grade-separated crossings. \\
\hline & Replace at-grade rail line with below-grade rail line. \\
\hline & Modify rail hours of operation. \\
\hline & Relocate rail yard. \\
\hline \multirow{2}{*}{$\begin{array}{l}\text { Improve Safety and } \\
\text { Security }\end{array}$} & Install upgraded rail crossings/barriers. \\
\hline & Create walls/pedestrian paths to reduce trespassing. \\
\hline \multirow{4}{*}{$\begin{array}{l}\text { Contribute to } \\
\text { Economic } \\
\text { Development }\end{array}$} & Relocate rail yard. \\
\hline & $\begin{array}{l}\text { Leverage a region's freight transportation system to create } \\
\text { economic value for the area. }\end{array}$ \\
\hline & $\begin{array}{l}\text { Adjust the freight transportation system to permit the } \\
\text { development of other types of property uses. }\end{array}$ \\
\hline & Create an industrial sanctuary. \\
\hline $\begin{array}{l}\text { Improve } \\
\text { Environmental } \\
\text { Performance }\end{array}$ & $\begin{array}{l}\text { Replace locomotives powered with direct current engines with } \\
\text { locomotives powered with alternating current engines. }\end{array}$ \\
\hline
\end{tabular}

Figure 2. Freight operations mitigation strategies

A number of these strategies with the potential for addressing multiple issues were further explored. These included trenching, elevating, walling, zoning, tunneling, bridging, relocating and capping. The following sections discuss the merits of these mitigation strategies. For each option, positive and negative attributes are highlighted and illustrations are provided when appropriate.

\subsection{TRENCHING}

This strategy allows roadways to remain at the existing grade and depressing the rail lines below the surface a depth sufficient to permit required train clearances. 


\section{Positive Attributes:}

- It eliminates auto/pedestrian and train conflicts.

- It eliminates at-grade crossing and the need for noisy signals.

- Depressed roadways or railways reduce noise to the neighborhoods. Vegetation near the edge of the trench can further help reduce noise.

- Trains are able to move more quickly through a corridor.

- It allows additional connectivity with additional bridges above the trench.

\section{Negative Attributes:}

- Construction costs are high.

- It is difficult to implement where there are pre-existing rail lines and activity.

- It limits future expansion to rail activities.

- It can provide rail maintenance challenges.
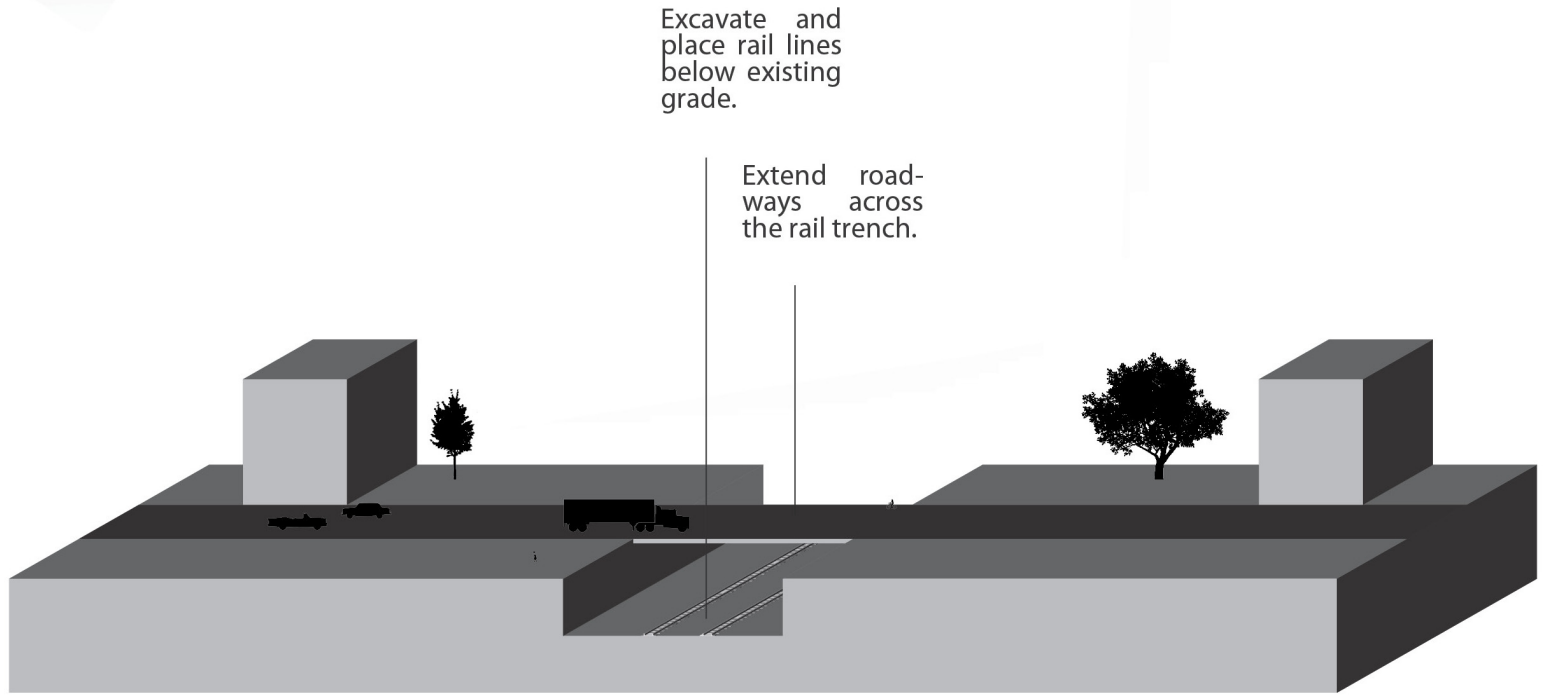

Figure 3. Trenching illustration

\subsection{ELEVATING}

This strategy involves relocating freight activities from the ground to an elevated platform, allowing non-freight transportation to cross below the rail yard.

Positive Attributes:

- The strategy provides complete separation between freight and non-freight transportation.

- Elevating the rail yard creates new territory below the platform for freight-related activity.

- It is possible to construct the platform without interrupting existing rail activity.

Negative attributes:

- Construction costs for a raised platform would be high.

- The strategy would potentially limit rail expansion and maintenance.

- The grade separation could negatively impact intermodal operations. 
- Raising the level of the rail yard could increase the impacts of noise on adjacent neighborhoods.

- Raising the level of the rail yard could increase its visual impacts on adjacent neighborhoods.

- Pedestrian/bicycle access under the platform could be experientially undesirable.

- Because of operational needs, the strategy may be better suited for rail lines rather than rail yards.

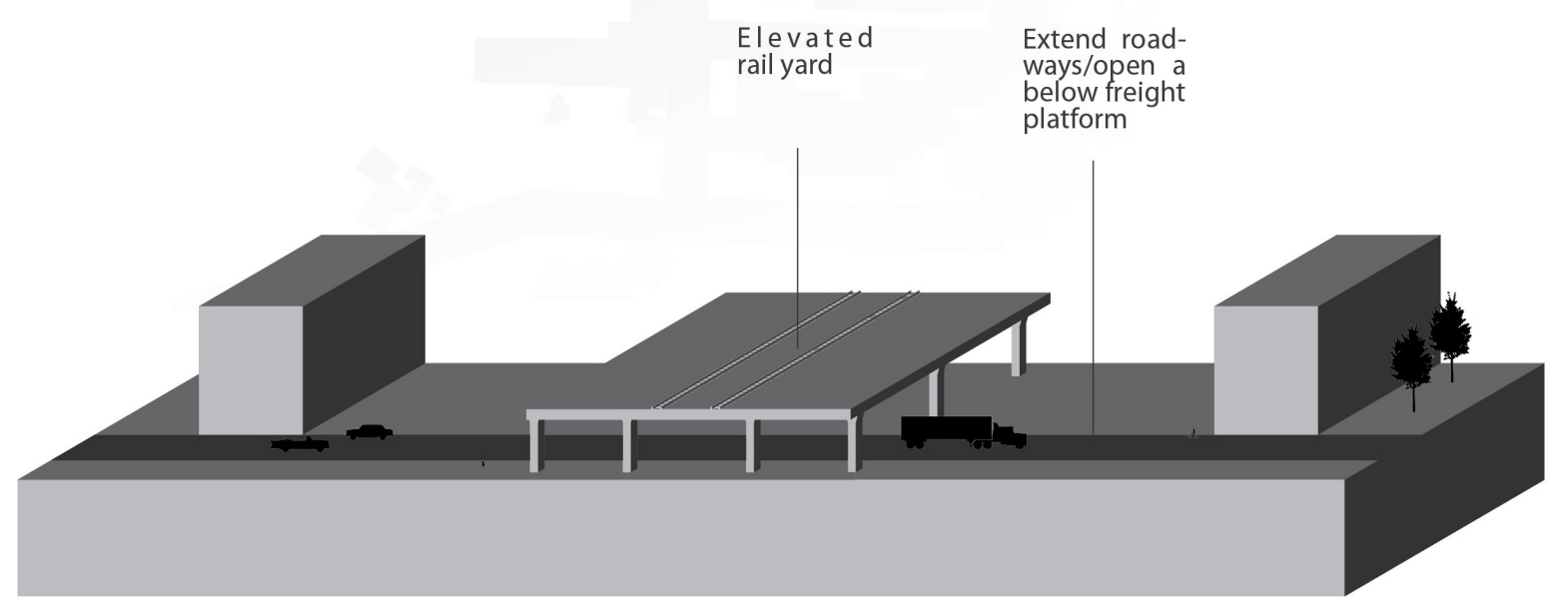

Figure 4. Elevating illustration

\subsection{WALLING}

Walling involves a nearly continuous solid barrier between the freight yard and adjacent uses. Tall earth berms are also consistent with this strategy. Walls that are angled to reflect the sound up, or absorptive to not reflect so much energy, help increase the attenuation provided. Upper levels of mid-rise or high-rise residential would get little or no attenuation. Vegetation that extends over the top of the walls will significantly reflect the sound over the walls and decrease the attenuation. The vegetation does not need to be located at the wall to have this effect. Tall trees near residences can capture sound higher in the environment and reflect it back down to listeners.

\section{Positive Attributes:}

- By eliminating access to the rail yard, walls can help address safety and security concerns.

- Walls can reduce the impacts of noise on the adjacent neighborhoods.

- Walls can improve the visual impacts of the rail yard.

- Walls have a relatively low construction cost.

\section{Negative Attributes:}

- Walls prevent desirable connections across the rail yard.

- If connections are made across the rail yard, they would not separate rail and non-rail forms of transportation. 


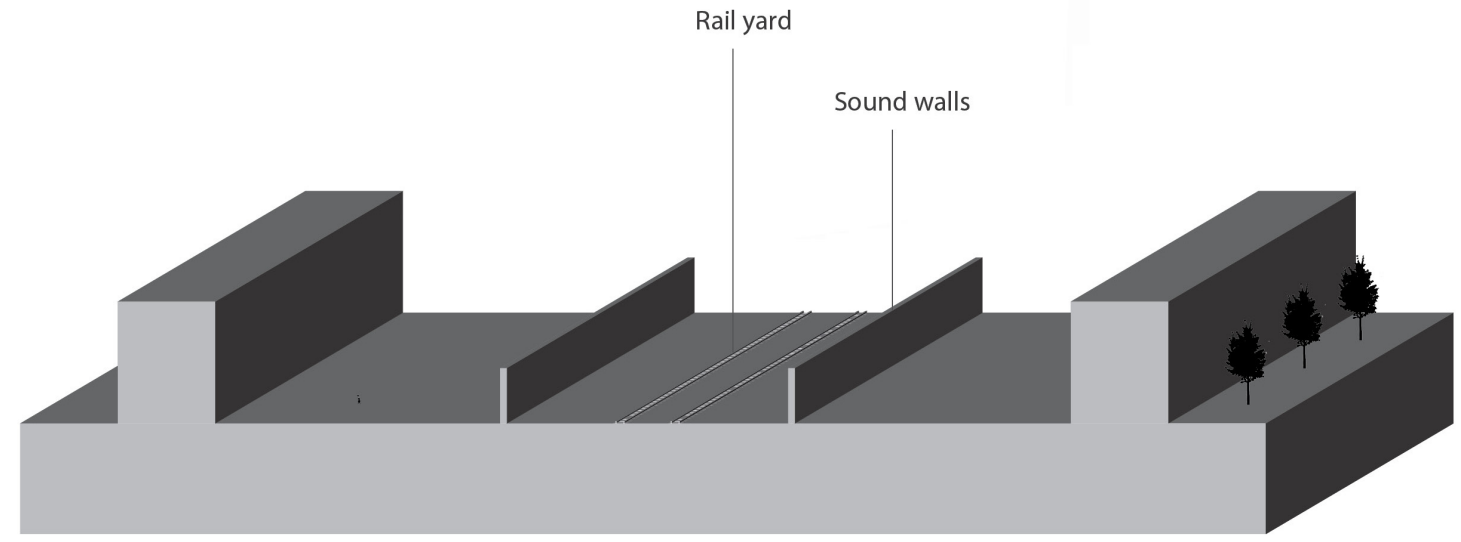

Figure 5. Walling illustration

\section{$5.4 \quad$ ZONING}

This strategy preserves non-residential uses where they exist and expands them around the rail yard where they do not. The idea is to keep a buffer zone of activities that are not adversely affected by freight rail activities between they rail yard and residential neighborhoods.

\section{Positive Attributes:}

- The expansion of industrial and commercial territory around the rail yard could support and be supported by freight rail.

- Changes to the zoning immediately surrounding the rail yard could make modest contributions to reducing freight rail operational noise.

\section{Negative Attributes:}

- Expansion of industrial and commercial uses around the rail yard would often be at the expense of existing residential uses.

- Additional industrial/commercial uses could increase truck and auto traffic in adjacent neighborhoods.

\begin{tabular}{l|l|l|l|l}
$\begin{array}{l}\text { Residential } \\
\text { zoning }\end{array}$ & $\begin{array}{l}\text { Provide/expand a zone } \\
\text { of non-residential de- } \\
\text { velopment to mitigate } \\
\text { impact of rail yard }\end{array}$ & Rail yard & $\begin{array}{l}\text { Provide/expand a zone } \\
\text { of non-residential de- } \\
\text { velopment to mitigate } \\
\text { impact of rail yard }\end{array}$ & $\begin{array}{l}\text { Residential } \\
\text { zoning }\end{array}$ \\
\hline & & &
\end{tabular}

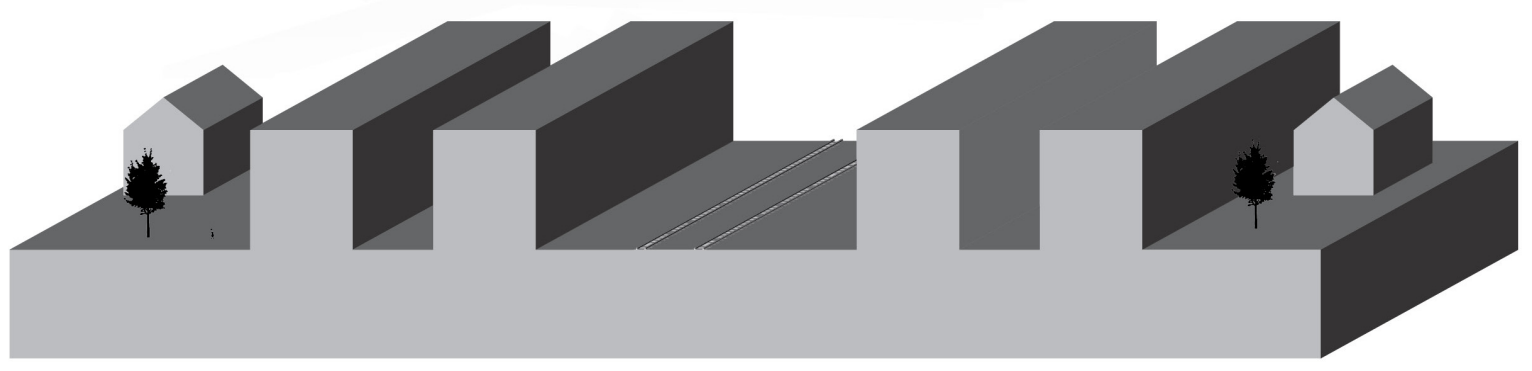

Figure 6. Zoning illustration 


\subsection{TUNNELING}

Tunneling is essentially providing an underpass for autos and pedestrians below the freight yard.

\section{Positive Attributes:}

- The strategy provides complete separation between freight and non-freight transportation.

- It is possible to construct the tunnel without interrupting existing rail activity.

\section{Negative Attributes:}

- Construction costs for tunnels would be high.

- Because of lighting and ventilation requirements, the operational costs could be high.

- The pedestrian and bicycle experience would likely be poor.

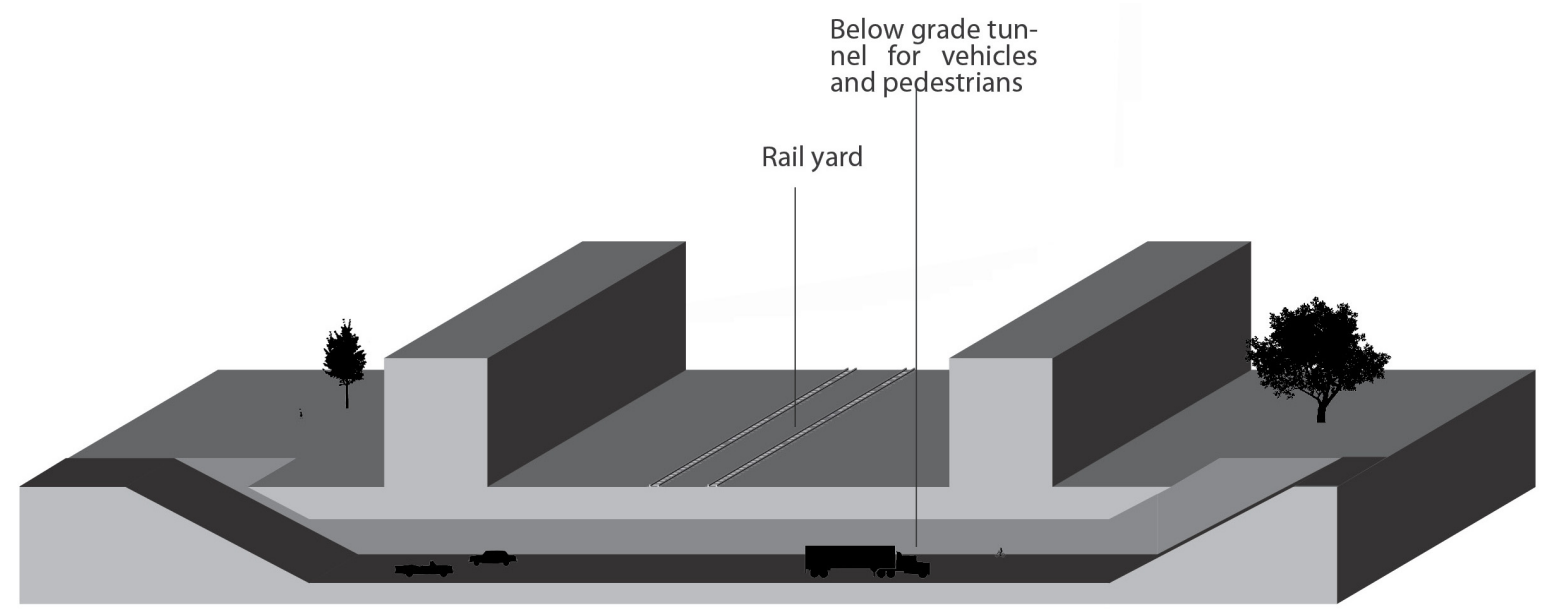

Figure 7. Tunneling illustration

\subsection{BRIDGING}

This strategy provides non-freight auto and pedestrian crossings over the rail yard with structures that span the freight activities.

\section{Positive Attributes:}

- The strategy provides complete separation between freight and non-freight transportation.

- It also provides a safe connection between neighborhoods and amenities.

Negative Attributes:

- The construction cost for this strategy is high.

- Little or no sound attenuation is provided without additional screening.

- Because of the length of the bridge over the yard, it is not a particularly desirable pedestrian connection. 


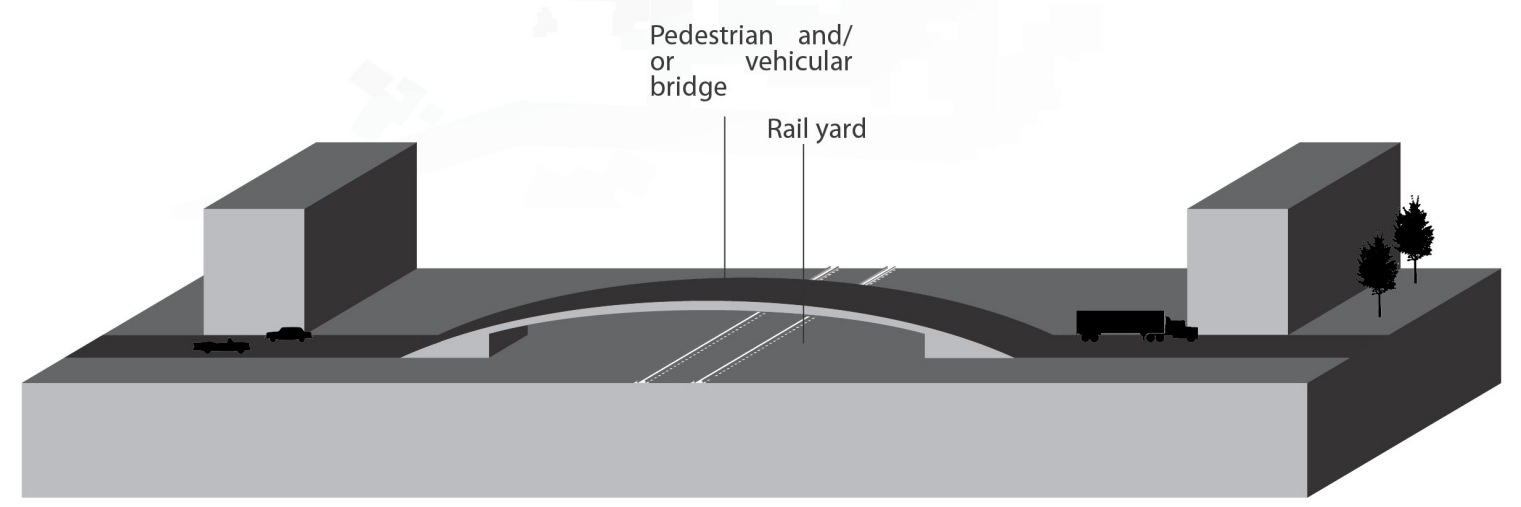

Figure 8. Bridging illustration

\subsection{RELOCATING}

In this strategy the entire freight rail operation would be moved to another location in the city.

\section{Positive Attributes:}

- All of the impacts of the rail yard would be relocated.

- The territory left behind would be available for new development consistent with the goals of adjacent neighborhoods.

\section{Negative Attributes:}

- Relocating the rail yard would be very costly.

- Moving the rail yard merely moves the impacts of the freight activity to another location.

- The adjacent neighborhoods would lose an employer and infrastructure necessary to other local employers.

\subsection{CAPPING}

This strategy is the development of the air rights above the rail yard. Like bridging it provides elevated connections for non-freight vehicles to cross the rail yard. However, in the case of caps, the scale of the bridges is wide enough to accommodate significant development. Capping opens up numerous development opportunities including: open space (Figure 8), retail/commercial development (Figure 9), and rail supported industries (Figure 10). Each of these strategies has similar positive and negative attributes noted below.

\section{Positive Attributes:}

- The strategy provides complete separation between freight and non-freight transportation.

- It provides a safe connection between neighborhoods and amenities. Unlike bridging, the quality of the connection for pedestrians and bicycles is enhanced by the addition of desirable development types on top of the cap.

- Capping has the potential to add amenities like parks and neighborhood retail to adjacent neighborhoods. 
- Capping can significantly reduce the impacts of operational noise on the adjacent neighborhoods.

- Caps can add land for stormwater management.

- A capping strategy can create additional space below the cap for freight operations by relocating uses adjacent to the yard to the top of a cap.

Negative Attributes:

- Caps have a high construction cost.

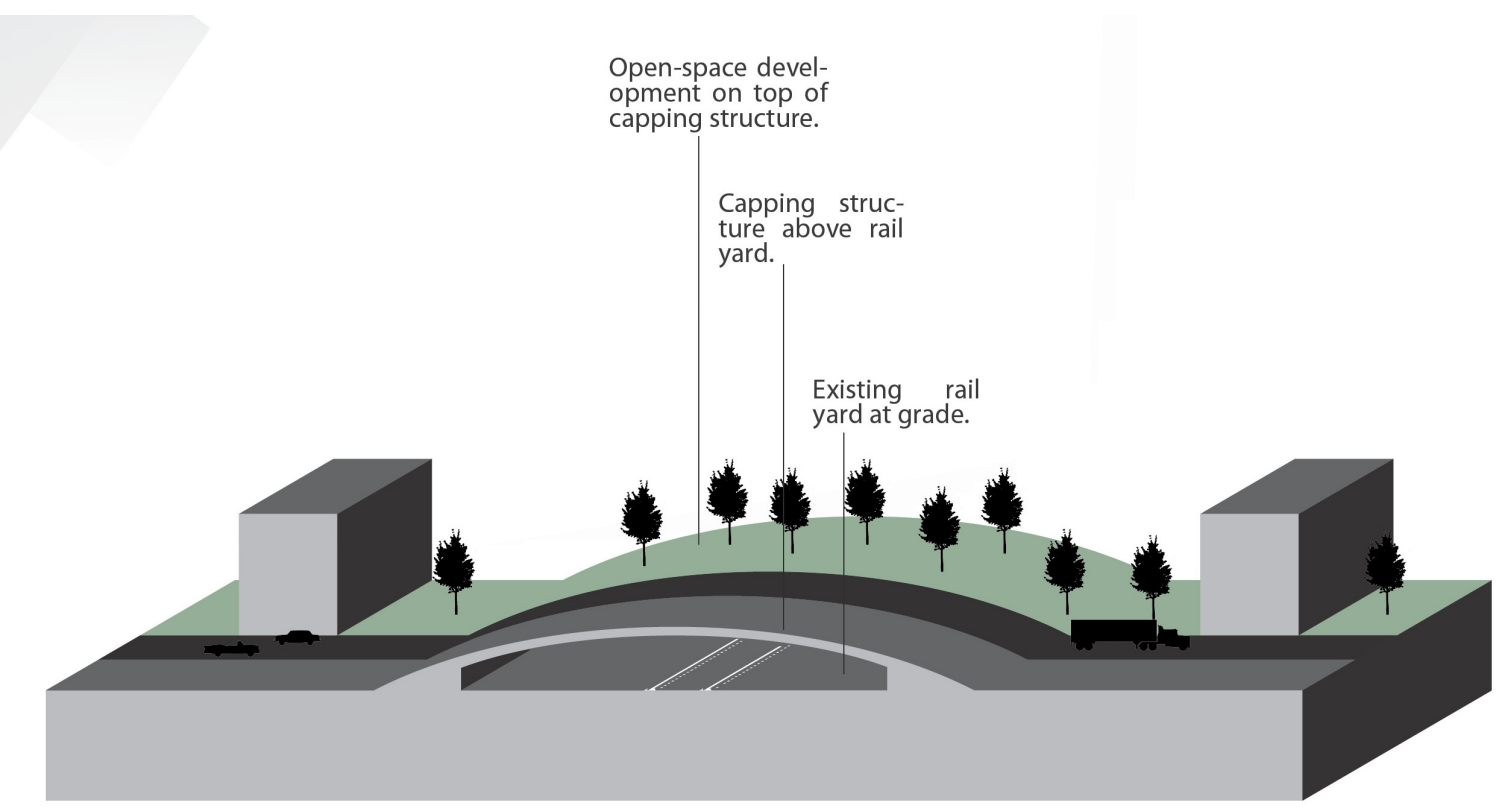

Figure 9. Cap with open space development

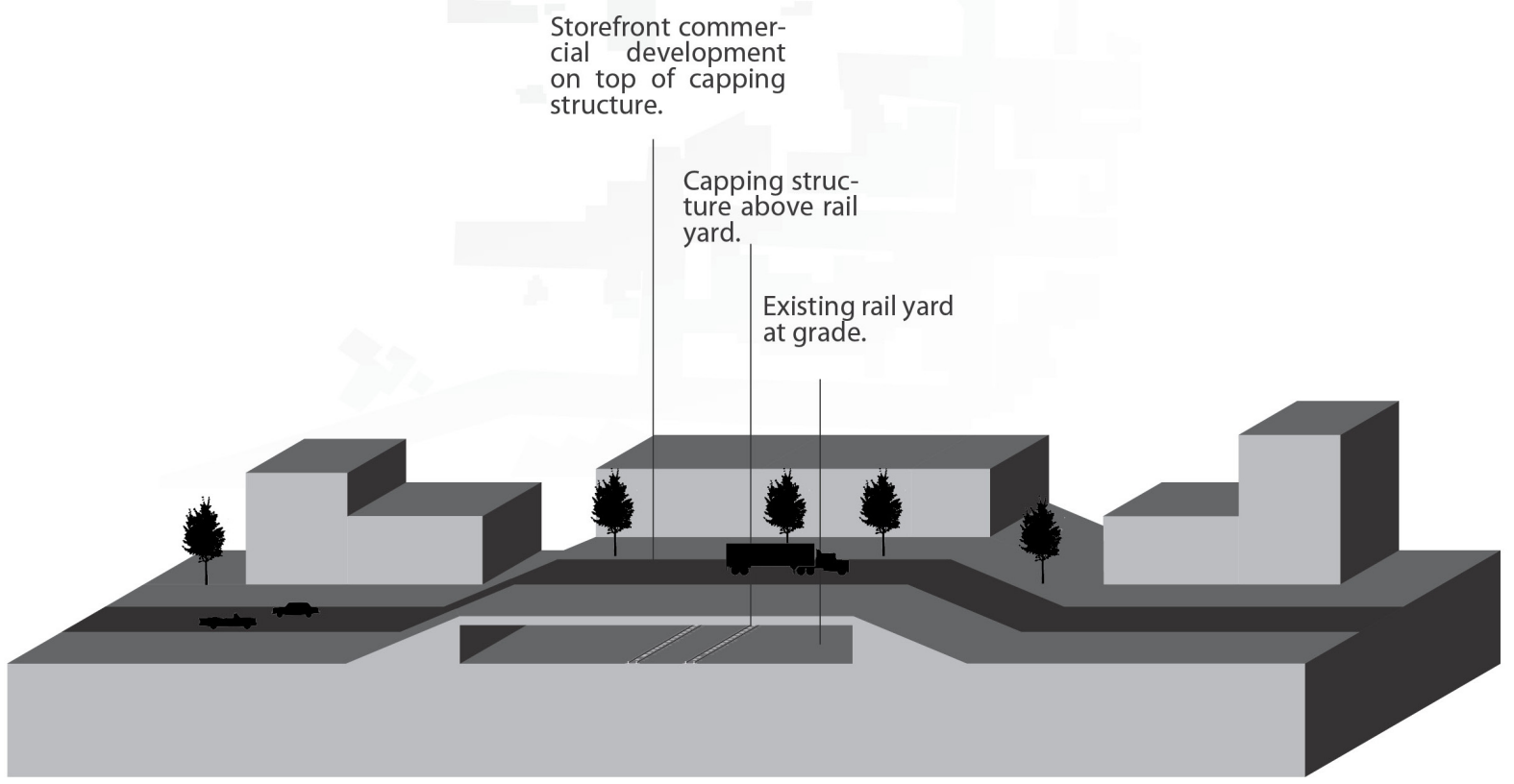

Figure 10. Cap with retail/commercial development 


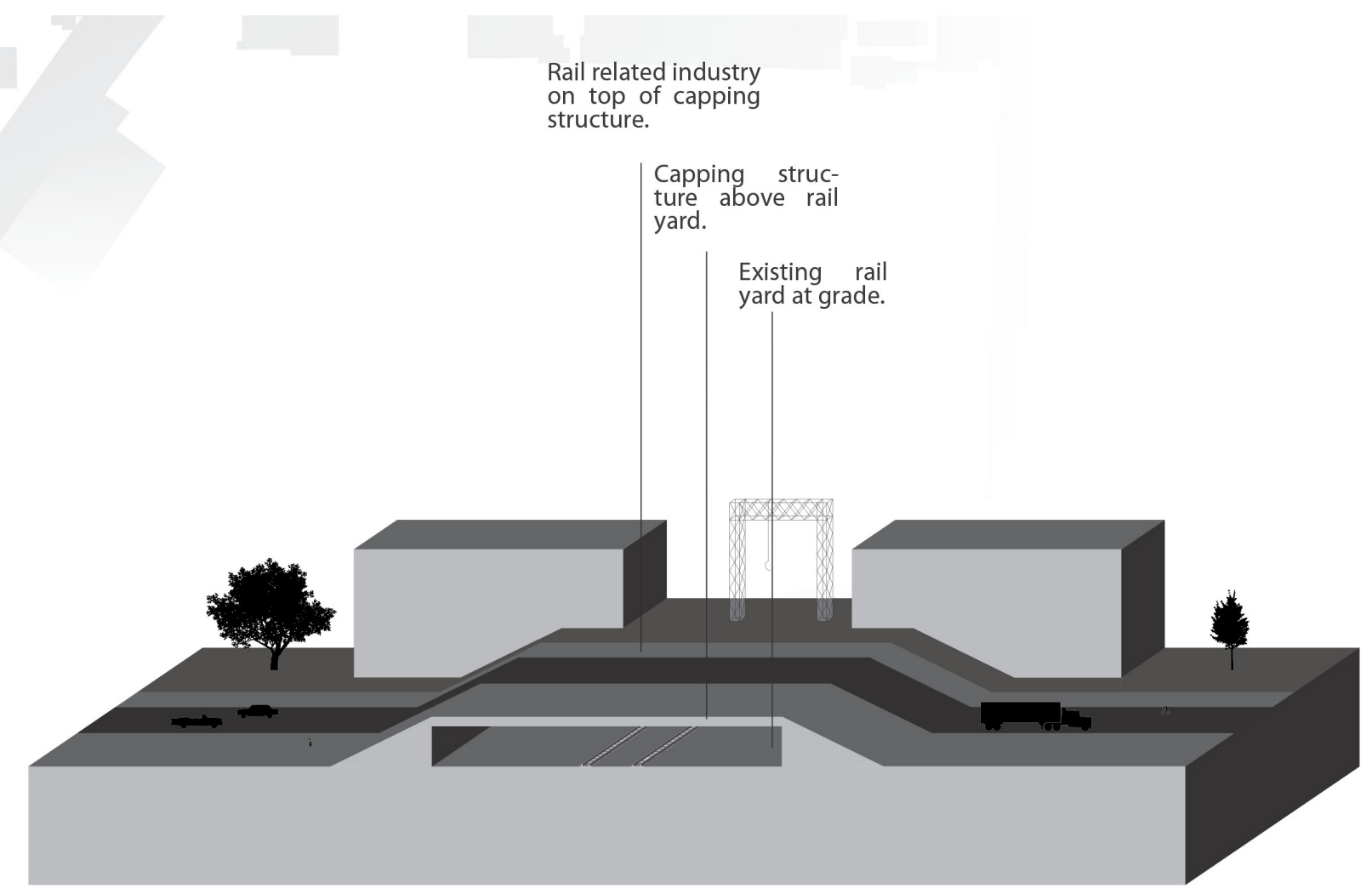

Figure 11. Cap with rail-related industry

Once the strategies were identified and illustrated, they were considered against the ability to mitigate impacts. Each strategy was categorized using high, med and low rankings against noise, visual impacts, congestion, safety, and environmental and land-value impacts as summarized in Table 1.

\begin{tabular}{l|c|c|c|c|c|c}
\hline & $\begin{array}{c}\text { Reduce } \\
\text { Noise }\end{array}$ & $\begin{array}{c}\text { Improve } \\
\text { Aesthetics }\end{array}$ & $\begin{array}{c}\text { Reduce } \\
\text { Congestion }\end{array}$ & $\begin{array}{c}\text { Improve } \\
\text { Safety }\end{array}$ & $\begin{array}{c}\text { Lessen } \\
\text { Environmental } \\
\text { Impacts }\end{array}$ & $\begin{array}{c}\text { Increase } \\
\text { Land Values }\end{array}$ \\
\hline Trenching & med & med & high & high & low & med \\
\hline Elevating & low & low & high & high & low & low \\
\hline Walling & med & med & low & med & low & low \\
\hline Zoning & med & med & low & low & low & med \\
\hline Tunneling & low & low & high & high & low & low \\
\hline Bridging & low & low & high & med & low & low \\
\hline Relocating & high 1 & high & high & high & high $^{1}$ & high $^{1}$ \\
\hline Capping & high & high & high & high $^{1}$ & high $^{2}$ & high $^{2}$ \\
\hline
\end{tabular}

Table 1. Mitigation strategies mapped against reduce impacts

(1) Strategy can open up opportunities on existing site but transfers same impact to new site

(2) Depends on the development type

(3) Provided that pedestrian/vehicular crossings are developed at frequent intervals 
Using the same rankings, each strategy was then evaluated against the ability to help address some of the high-priority Union Pacific and community goals. These goals included eliminating track constraints, expanding the area for intermodal containers, creating east/west pedestrian access, connecting communities to the river, expanding greenspace and creating new development opportunities (see Table 2).

\begin{tabular}{l|c|c|c|c|c|c}
\hline & $\begin{array}{c}\text { Eliminate } \\
\text { Track } \\
\text { Constraints }\end{array}$ & $\begin{array}{c}\text { Expand } \\
\text { Area for } \\
\text { Intermodal } \\
\text { Containers }\end{array}$ & $\begin{array}{c}\text { Create } \\
\text { East/West } \\
\text { Pedestrian } \\
\text { Access }\end{array}$ & $\begin{array}{c}\text { Connect } \\
\text { Communities } \\
\text { to the River }\end{array}$ & $\begin{array}{c}\text { Expand } \\
\text { Green- } \\
\text { space }\end{array}$ & $\begin{array}{c}\text { Create New } \\
\text { Development } \\
\text { Opportunities }\end{array}$ \\
\hline Trenching & low & low & high $(2)$ & low & low & low \\
\hline Elevating & low & med & high & low & low & high \\
\hline Walling & low & low & low & low & low & low \\
\hline Zoning & low & med & low & low & low & med \\
\hline Tunneling & low & low & high & low & low & low \\
\hline Bridging & med & low & high & med & low & low \\
\hline Relocating & high & high & high & high & high $^{3}$ & high $^{3}$ \\
\hline Capping & high & high & high & high & high $^{4}$ & high $^{4}$ \\
\hline
\end{tabular}

Table 2. Mitigation strategies mapped against community/Union Pacific goals

(1) Assumes new rail yard expands capacity

(2) The quality of the pedestrian/bicyclist may be low

(3) Depends on new uses proposed for the abandoned rail site

(4) Depends on the development type 


\section{THE CASE FOR CAPPING}

Based on the options presented in Section 5, capping, though more costly, has some significant advantages to other strategies in terms of reducing noise, improving neighborhood connectivity and lessening environmental impact. From an acoustical standpoint, capping offers the best opportunity to decrease the impact of noise to adjacent communities. Capping provides a clear separation between modes of transportation. Unlike bridging and trenching strategies, the addition of development opportunities on the cap adjacent to roadways/walkways creates a better environment for bicycling and walking. These same development opportunities would help to connect retail and open space currently separated by the Brooklyn Rail Yard.

With the addition of land above the rail yard comes the opportunity to add new retail, light industrial or rail-related development. It also provides an opportunity to relocate existing activities that are currently adjacent to the rail yard to newly created space above the rail yard. This gives Union Pacific Railroad the flexibility to expand and modify the yard configuration to increase capacity and improve efficiency. By concealing less desirable areas of the rail yard, the value of adjacent properties has the potential to be enhanced. Capping would improve the visual impact on adjacent neighborhoods. Capping also has the potential to reduce trespassing by eliminating desired lines through the rail yard.

The Union Pacific Railroad could potentially generate income from the sale or lease of the new land above the rail yard. These revenues could then be used to make upgrades within the rail yard that positively affect the impacts of the yard on adjacent neighborhoods.

Capping would also have some environmental benefits. Portions of the new territory created by capping can be assigned to green roofs and water treatment landscapes that contribute to the community's stormwater management plans. Adding appropriate vegetation to the new design would help improve both the air quality and the heat island effect. 


\section{A CAPPING STRATEGY FOR THE BROOKLYN RAIL YARD}

For the purposes of this investigation, four potential capping sites have been identified. The number and location of these sites was selected as a means of illustrating the potential of this strategy to mitigate impacts and create amenities for the adjacent stakeholders in this project. All of the locations build on the possibility of making multimodal street connections across the rail yard and make connections between communities and destinations. Currently, Holgate Boulevard is the only connecting street for nearly three miles of the rail yard. The connections also relate closely to the proposed locations for TriMet light rail stations that, in the current conditions, would only be accessible from the west side of the rail yard. The size of each cap would vary significantly based on the land uses on top. This report illustrates the potential scale for two of the four caps again to simply illustrate the potential of the capping strategy. The final configuration and use for any cap must undergo significant input from all of the community stakeholders, as discussed in the "Next Steps" portion of this report.

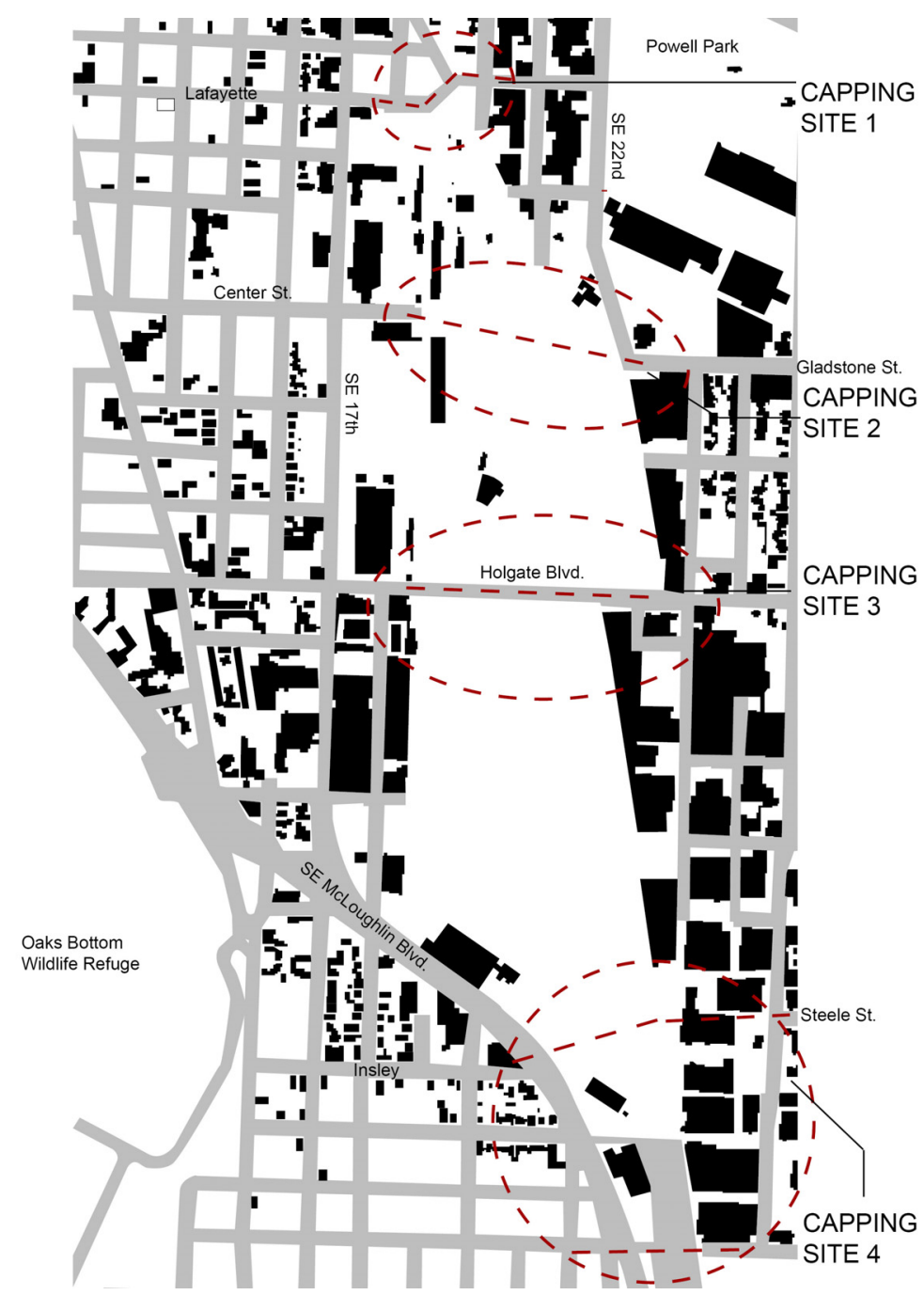

Figure 12. Proposed capping sites 


\section{Capping Site One: Lafayette Street Connection}

The northernmost location on the site would cover rail lines rather than the rail yard. It is the location where a pedestrian bridge currently exists. Because of the existing topography and narrow width of the railroad right-of-way, the Site One cap would likely require partial or full trenching of the rail lines in order to meet the train clearances. A cap in this location could reconnect Lafayette Street for cars, pedestrians and bikes. The proposed cap could make a new connection from the Brooklyn Neighborhood to Powell Park, which now relies on the heavily traveled Powell Boulevard. The new connections could make strong linkages from east-lying neighborhoods to a light rail line proposed by TriMet.

\section{Capping Site Two: Center/Gladstone Streets}

This proposed capping location would connect Center Street to Gladstone Street. A cap in this location has the potential to expand the territory below the cap for the storage and staging of intermodal train cars while providing an intermediate connection point for cars, bicycles and pedestrians. Gladstone Street is a collection of residential and commercial activity to the east and light industrial and warehousing adjacent to the rail yard, so there is a range of viable building types for the top of this proposed cap. The cap would make connections to a proposed light rail station and take development cues from that adjacency. A cap in this location could incorporate connections to desired routes for intermodal truck traffic and take some of that traffic off of Holgate Boulevard.

\section{Capping Site Three: Holgate Boulevard}

This proposed cap location flanks both sides of the Holgate Boulevard overpass. As indicated earlier in this report, the abutments of the overpass currently constrain the rail operations. A new cap in this location could improve this condition. A possible development strategy for the caps would be to extend the commercial/retail uses that exist, albeit sporadically, along Holgate Boulevard. This site would create a more desirable bicycle and pedestrian connection from the eastern neighborhoods to the river, the 40-Mile Bicycle Loop and downtown Portland. The cap could allow for better stormwater management, which is an issue with areas close to the river. The cap would also make connections to a proposed light rail station.

\section{Capping Site Four: Steele-Insley Street Connection}

This is the southernmost capping location proposed for the rail yard. In this location there is a potential to connect Steele Street with Insley Street on the opposite side of McLoughlin Boulevard. While the primary goal of the caps is to mitigate the impact of the rail yard, this cap has the unique opportunity to extend over McLoughlin, a major barrier to east west connections.

This cap is also adjacent to a proposed light rail station. A cap located here would make a strong connection to the station from the Eastmoreland neighborhood and nearby Reed College. This cap could be topped with significant park space as a way of making a connection between the existing Rhododendron Garden, and the Eastmoreland Golf Course to the east with Westmoreland Park and Oaks Bottom Wildlife Refuge to the west. Surrounded by McLoughlin Boulevard and a significant amount of industrial/warehouse uses, this cap could support additional freight-related uses. Under the cap, the rail yard could be widened to facilitate the building-up of trains and the storage of cars so that the impacts of the rail activity to the south of the yard are reduced. 


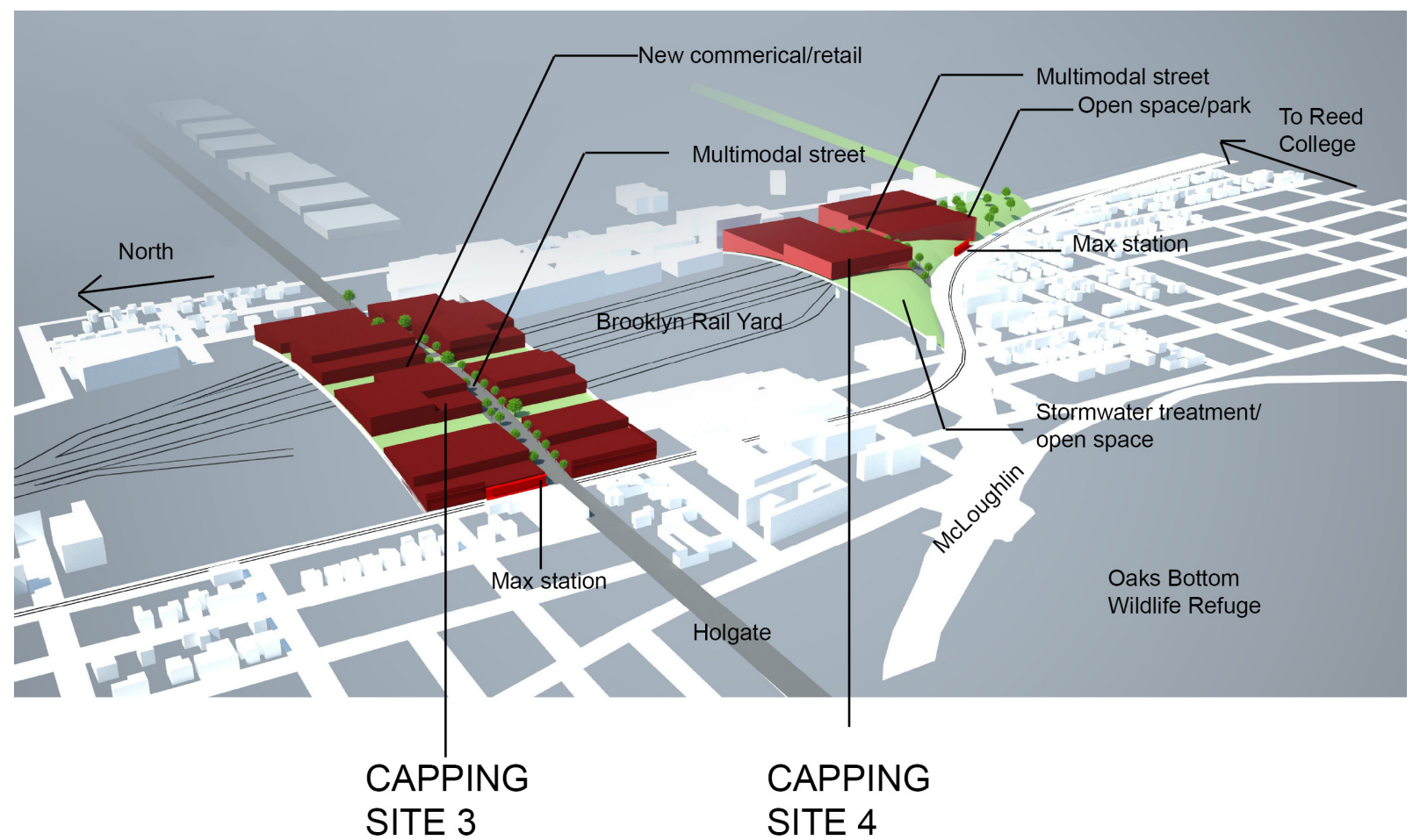

Figure 13. Aerial model showing the potential placement of caps over the rail yard and integration with the adjacent neighborhoods 


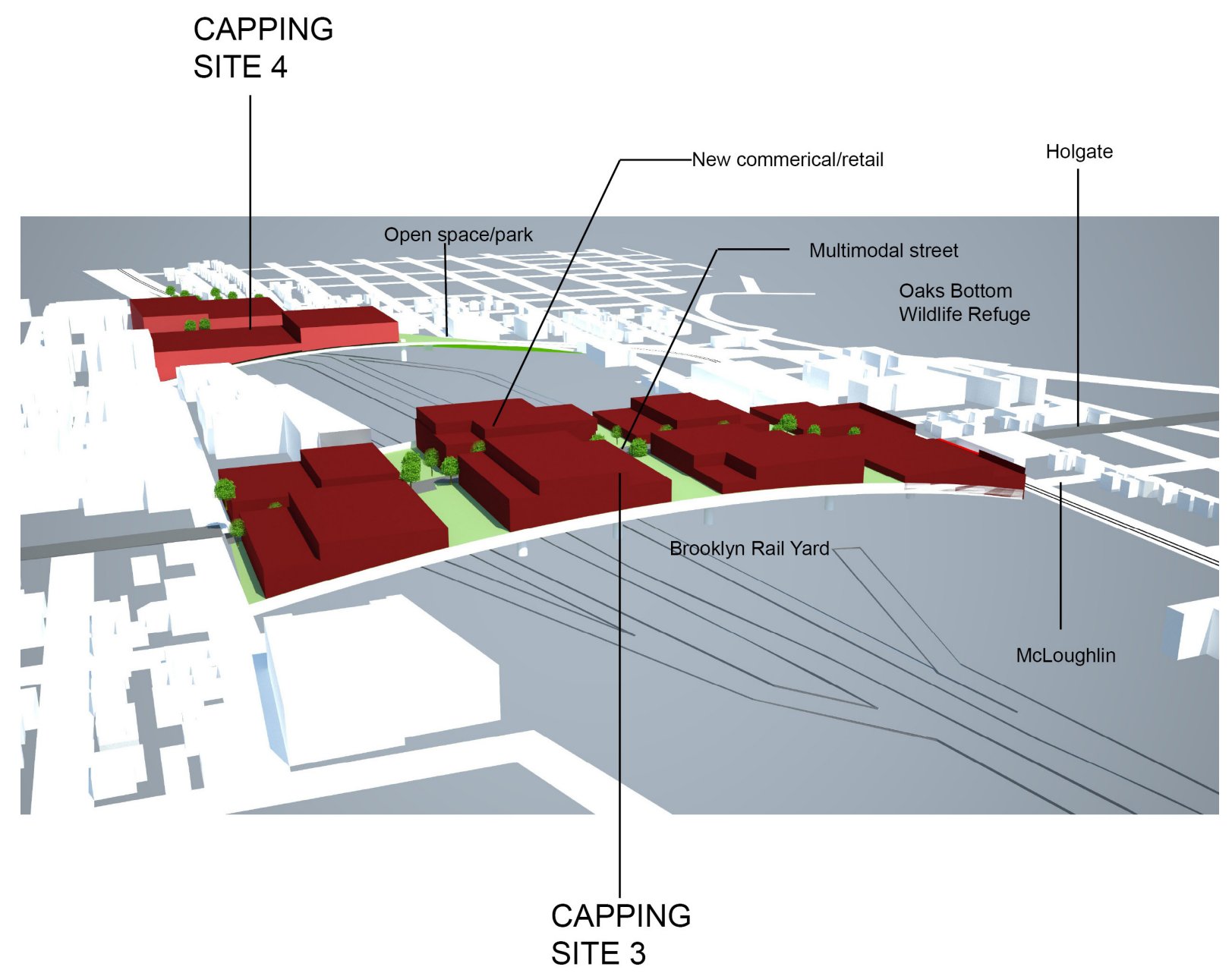

Figure 14. Another aerial model showing the potential placement of caps over the rail yard and integration with the adjacent neighborhoods 


\section{CONCLUSION}

There seems to be enough literature to suggest that for the foreseeable future freight rail remains an important part, perhaps an expanding part, of national and local transportation strategies. Even on the neighborhood level there is recognition of the economic importance of the Brooklyn Rail Yard. If we conclude that Union Pacific Railroad and the City of Portland are best served by keeping the Brooklyn Rail Yard in place, then the impacts of the facility must be dealt with on site. This case study has identified many of the impacts created by the existence of freight rail in urban settings and by the Brooklyn Rail Yard in particular. This study acknowledges that there are many operational and physical modifications that can improve the impacts of freight rail. But it appears none of these strategies can provide the full spectrum of improvements while at the same time contribute to community goals and Union Pacific operations like capping appears to be able to accomplish. For this reason, this study suggests that capping warrants consideration as a mitigation strategy.

Assumptions have been made about the relative value of various mitigation strategies. This study was conceived as a means of capturing those assumptions for testing against the perceptions of adjacent neighborhoods, city agencies and Union Pacific Railroad. Further, the study makes the case for capping as a viable mitigation strategy for the Brooklyn Rail Yard. This too must be tested with the aforementioned stakeholders. Finally, for the purposes of illustrating the capping strategy, assumptions were made about the number, location, size and program of the caps. These decisions must ultimately be made with a comprehensive study that engages a full spectrum of disciplines and stakeholders. 


\section{NEXT STEPS}

If the stakeholder response is positive to the assumptions that the rail yard should remain and that the capping strategy appears to have merit, then the next step would be to identify a specific location in the rail yard that could serve as a viable demonstration project. This demonstration project should include:

- Working with city agencies, neighborhoods and Union Pacific to determine the most desirable uses for the territory made available on the top of the caps.

- Developing a more detailed understanding of rail operations, clearance requirements, etc. that reveal the potential contributions and impacts of a capping strategy on the rail yard.

- Working with Union Pacific Railroad to determine the modifications required to improve operations below the proposed cap(s).

- Assembling a design team of architects, landscape architects, planners and engineers to make a proposal for the design of the preferred capping site.

- Generating preliminary engineering to determine the structural and infrastructure requirements for the project.

- Preparing estimates of soft and hard construction costs to determine the financial requirements of the project.

- Exploring financing strategies and potential funding sources to determine the economic feasibility of the project.

- Soliciting responses from all stakeholders at regular intervals to maximize the benefits of the project as it is developed. 


\section{BIBLIOGRAPHY}

AASHTO. (2003). Transportation Invest in America: Freight Rail Bottom Line Report. Washington, DC: American Association of State Highway and Transportation Officials. American Society of Landscape Architects. (1998). Bridge the Divide and Cap I-405 Vision Studty. Portland, OR: Portland Development Commission.

Cambridge Systematics Inc. (March 2004). Freight Rail and the Oregon Economy. Port of Portland.

Metro. (1999). Commodity Flow Analysis for the Portland Metropolitan Area.

NCHRP. (2003). NCHRP Synthesis 320: Integrating Freight Facilities and Operations with Community Goals. Washington, DC.

NCHRP. (2004). 2010 and Beyond: A Vision of America's Transportation Future, 21st Century Freight Mobility - NCHRP Project 20-24(33). Washington, DC.

NCHRP. (2007). Guidebook for Assessing Rail Freight Solutions to Roadway Congestion. Washington, DC.

NCHRP. (2007). Report 586: Rail Freight Solutions to Roadway Congestion-Final Report and Guidebook. Washington, DC.

State of Oregon. (May 2004). Background Brief on Freight and Passenger Rail. Legislative Committee Services. 


\section{APPENDIX A. NEIGHBORHOOD SURVEY AND RESPONSES}

1. What do you feel are the positive attributes of the Brooklyn Rail Yard?

- "The yard is the historic focal point of the neighborhood. It provides family wage jobs, and supports the local industrial economy." (Brooklyn Action Corps Neighborhood Association, BAC)

- 'Employment, an important part of the City's and Nation's transportation infrastructure, an overall economic asset" (Sellwood Moreland Improvement League, SMILE)

- "Inter-modal freight capacity creates jobs, and facilitates the use of lower polluting options (rail v. truck) for freight transport." (Creston - Kenilworth Neighborhood, CK)

- "I think the rail yards provide a necessary area for moving goods to and from the city / region. People often forget this aspect when discussing issues like freight train horn noise and pollution." (Hansford - Abernathy, HAND)

2. Are you aware of any complaints / concerns about traffic regarding the Brooklyn Rail Yard?

- "Yes, complaints have increased in recent years. Heavy truck traffic has been on the increase. Contract truck drivers are not from the area and get lost going to and from the yard. This means that trucks end up going down residential streets..." (BAC)

- "Yes, regarding truck traffic, although most of that manages to stay on Holgate Boulevard. Both the Sellwood-Moreland and Eastmoreland neighborhood associations had participated in overseeing a US District Court order restricting freight yard activity south of Reedway Street. The neighborhoods generally recognize that train movement can and will occur on the mainline tracks that run between these neighborhoods but oppose an expansion of yard oriented train movement in this section." (SMILE)

- "No, This area seems very underutilized from an auto and freight truck standpoint." (HAND)

3. Are you aware of any complaints / concerns about noise regarding the Brooklyn Rail Yard?

- "Yes, the general noise level has increased in recent years. New federal guidelines on the sounding of warning horns is to blame. The increased use of robotic locomotives also seems to play a role in the increasing noise level. The noise created by the switching and coupling of rail cars is minimal" (BAC)

- "This was the subject of a lawsuit some years ago. My understanding is that an agreement was put into place to try to minimize this problem for the nearby neighbors." (SMILE)

- "Not only noise from apparently unnecessary whistle alerts (there are no highway crossings from SE Clinton/ $11^{\text {th }}$ and $12^{\text {th }}$ until the city of Milwaukie) but also from safety alarms that sound almost continuously in the movement of intermodal cranes that operate in the yard. At one point the railroad commissioned a study by a national expert who concluded that the noise from yard activity was indistinguishable from urban background, such as McLoughlin Boulevard. They were able to conclude this by averaging the distinctive bursts of loud noise from rail activities so as to drop the peaks from any record." (SMILE) 
- "None have been voiced to me lately, however I have heard complaints in the past about both the train horns and the banging of cars being connected as trains are reconfigured in the yard." (CK)

- "Other than train horn noise, I have not heard complaints regarding other activities from the Yards projecting noise into the neighboring residential zones..." (HAND)

4. Are you aware of any complaints / concerns about safety regarding the Brooklyn Rail Yard?

- "Pedestrian access over and around the yards is very poor and needs to be improved. Using the legal pedestrian facilities is almost as dangerous as trespassing through the rail yards."(BAC)

- "A teenage boy was killed a couple of years ago when he tried to cut through the Yard using a hole in the fence instead of the elevated walkway which has been constructed for this purpose. Also, there are some concerns about remotely operated locomotives." (SMILE)

- "A concern had been raised at one meeting about storage of unknown hazardous materials in rail cars at the yard. However, it was a concern not a fact based finding." (SMILE)

- "Not a problem with the yard per se, but I don't know anyone who is willing to use the pedestrian under-crossing on Powell due to concerns about getting waylaid under the railroad crossing, and about homeless camping/ sleeping there." (CK)

- "No." (HAND)

5. Are you aware of any complaints or concerns about pollution regarding the Brooklyn Rail Yard?

- "Yes, though seldom discussed, I suspect that the ground is very contaminated in this area from the many years of rail yard operations." (BAC)

- "Neighbors took action against the railroad to prevent contamination from disposal activities in the Brooklyn rail yard into Crystal Springs Creek. The trucks that use the yard were described once as POS or pieces of fecal matter to describe them as being generally much older and more polluting than most trucks. UP admits that they have not purchased switch engines since virtually the 1960s, thus the equipment is polluting. California ARB requires the railroads

- operating there to characterize the emissions impacts from rail yard. In some cases, the elevated cancer to residents, even up to 10 miles away is significantly above background. UP has resisted taking advantage of Oregon tax credits and other incentives to upgrade locomotives in Oregon." SMILE)

- "I have not heard any (concerns). My concern is that idling of trucks be kept to a minimum." (CK)

- "No, although I imagine that pollution and brownfield sites exist." (HAND)

6. Do you feel that the Brooklyn Rail Yard is a barrier to your connection to other neighborhoods or nearby destinations?

- "Yes, without a doubt. Many streets that used to cross the railroad were closed for security reasons with the onset of World War II. The war ended, but all of these streets have remained closed. This leaves very little legal access across the yards. The pedestrian underpass near SE Rhine Street is in very poor condition. The sidewalks along Holgate are poorly maintained, and very uninviting to use. The pedestrian underpass at SE Powell is 
poorly lit, poorly maintained, smells of urine, and is often impassable due to the large number of homeless people that congregate and sleep here. All of these routes are very unfriendly, if not outright treacherous, for bicycling as well" (BAC)

- "If the Harold Street Station on the proposed Max line were to ever be constructed, it would take a major effort to figure out how to get people from the Eastmoreland side of the Yard over to the Station." (SMILE)

- "Even without the Brooklyn Yard there would still be McLoughlin Boulevard to exist as a barrier to full connectivity with neighborhoods to the east. However, the yard and the associated rail lines pose a greater barrier than the highway. The neighborhood advocated for and planned with zoning changes for the South-North light rail line. This transit connection, to parallel the mainline tracks and McLoughlin Blvd, was originally to have a station at Harold Street. However in the recent planning effort the station was dropped from near term construction due to the cost of building a pedestrian crossing over the railyard tracks. This would have allowed better access to Reed College and the Reedway neighborhood." (SMILE)

- "Definitely a bike and pedestrian barrier between Creston-KJenilworth and Brooklyn. Need improved pedestrian and bike accommodations at both Holgate and Lafayette pedestrian bridge. Would prefer a more central pedestrian / bike crossing (such as at Gladstone, or Bush). The difference in distance is trivial for cars, but a major barrier to pedestrians..." (CK)

- "No. I think McLoughlin Blvd. and Powell Blvd. are the real dividers between the neighborhoods surrounding the yards." (HAND)

7. Are you aware of any complaints / concerns about the visual impact of the Brooklyn Rail Yard?

- "The yards are very ugly and uninviting. There used to be more in the way of a landscaped buffer around the yards, but this has been both neglected and actively destroyed in recent years in the name of expansion and improved security." (BAC)

- "It's a remnant of the old industrial economy of Portland and most of the people I know who live in the Sellwood Moreland neighborhood (I think) feel the same way." (SMILE)

- "Storage of rail cars on the mainline tracks south of SE Reedway had been a prohibited condition in the District Court ruling." (SMILE)

- "Main concerns are with graffiti on train cars and on adjacent buildings." (CK)

- "I enjoy driving over the bridge and looking down on the yards..." (HAND) 



\section{GOTREC \\ AND EDUCATION CONSORTIUM}

P.O. Box 751

Portland, OR 97207

OTREC is dedicated to stimulating and conducting collaborative multi-disciplinary research on multi-modal surface transportation issues, educating a diverse array of current practitioners and future leaders in the transportation field, and encouraging implementation of relevant research results. 